\title{
The Effect of Using Suggestopedia Among Students' Speaking Ability
}

\author{
Yuli Puji Astutik \\ STIT Muhammadiyah Tanjung Redeb, Berau, East Kalimantan, Indonesia \\ jasmine_ypa@gmail.com
}

\begin{abstract}
Speaking is an important skill to communicate in the globalization era. We cannot deny the failure is caused by many problems. The success of the learning is involved in complex things, especially in the lecturer's ability in learning and teaching. Such as the interesting material, the using of media, the learning approach and strategy, the classroom management, school environment, completely facilitation, and many other aspects. The objective of this research is to find out the effect of using suggestopedia to the students' speaking ability. The group had taught by using suggestopedia. It had conducted a pre-testing them first, then gave them treatment using suggestopedia and the last conducted a post-test. The instrument was used oral performance test. The criteria of the performance test scoring were a fluency, accuracy, content, and pronunciation. According to the result of statistical calculation, it is obtained the value of ( $t$-observation) is 8,387 and the value of "tc" ( $t$-critical) from the $\mathrm{df}$ (31) on degree of significance of $0,05 \%$ is 1.6955 . Based on the finding of this study it can be concluded that using suggestopedia method in increasing students' speaking ability is effective.
\end{abstract}

Keywords: Suggestopedia, students' speaking ability

Citation APA Style: Astutik, Y. P. (2019). The Effect of Using Suggestopedia Among Students' Speaking Ability. English Language in Focus (ELIF), 1(2), 137-144.

\section{INTRODUCTION}

$\mathrm{E}$ nglish nowadays is one of the cornerstones in daily living and encounters. It has become an important language of economy, science, business, aviation, entertainment, radio, air transportation, news, education, and diplomacy. Jackson (2010) points out that English is not only used when people communicate with native speakers, but it is also used when people from different nations meet. We cannot deny that English is an international language has been used all over the world. Therefore, people must master English in order to make an understanding of one another in communication.

Speaking is a process to convey and sharing ideas and feeling orally. Speaking involved some skills such as accuracy, appropriateness, fluency, and vocabulary building. All of those elements need to be mastered by the students. Therefore, if students do not learn how to speak or do not get any opportunities to speak in the language 
classroom, they may soon lose their interest in learning. From the observation in the class in STIT Muhammadiyah, Tanjung Redeb, Berau, the writer found that in teaching and learning English has given to each class. However, this is not maximum because the condition of the class does not support, for instance the noisy class. Besides, there are many problems in teaching speaking. First, it related to the condition of students who are lack of vocabulary. Second, the students regular to speak their mother tongue "Bahasa Indonesia" although they were involved in English class. Third, they are rarely to practice to use English for communication. The last they were not interested in the material given especially in teaching speaking.

To cover the problems and make the teaching learning process more interesting, the teacher should use an interesting technique that makes students enjoy and not afraid of making mistakes. One of the interesting method is Suggestopedia method. It is one of the methods of teaching English. In this Suggestopedia method, the students will do an interesting activity. Every student will get a turn to speak with their partner so they will be motivated to be brave in giving opinion or say something.

This method can be used for sharing information to learn the other subject. In this method doesn't take place in the competition, in this method the students will share information and the discussion occurs to students in pairs when presentation topics during the lessons.
The Definition of Speaking

Speaking is a language, language is essentially speech, and speech is basically communication by sounds. According to Richards \& Renandya (2002), speaking is especially difficult for foreign language learners because effective oral communication requires the ability to use the language appropriately in social interactions. Speaking is one of the elements of communication, where communication is the output modality and learning is the input modality of language acquisition.

It can be said speaking skill or ability is the capability to other the articulation to express, to state or deliver though, opinion and wish to the other person. From some definitions above, the researcher can conclude that speaking is one of skill of language which has essential role in human interaction and communication. When humans communicate by means of spoken language or speaking, they can express meanings that are conveyed through sounds. That is why speaking ability is an important process of English learning.

\section{The Aspect of Speaking Ability}

The process of speaking is used to be able to speak well and right. Referring to the aspect of speaking skill, Nurgiyantoro (2011) stated that in order to be able to speak in a language, the speaker has to mastery the pronunciation, grammar, and word. It can be said that the aspect of speaking ability is determined by utterance, vocabulary, grammar, content, fluency, 
comprehension, the appropriate of words choice, familiar, and placement of stress.

\section{Definition of Suggestopedia}

Before going to the concept of Suggestopedia, it will be better to know what Suggestopedia is. There are some definitions of Suggestopedia stated by some experts. Suggestopedia It is a method developed by Georgi Lozanov. He is the Bulgarian psychiatrist-educator. Lozanov (2000) describes Suggestopedia as science that concerned with the systematic study of the non Rational or no conscious influences. The influence of Suggestopedia is used to optimize the learning process. Besides, they also state that a most conspicuous feature of Suggestopedia in the centrality of music and musical rhythm to learning. The music is played in Suggestopedia gives suggestion and creates a relaxed situation. Song and music can be used to . relax the students and providing an enjoyable classroom atmosphere. By playing the music, it will decrease the students' boredom.

Suggestopedia helps the students to feel relax and fun approximately three times as quickly as conventional

\section{Presentation}

The main aim in this stage is to help students relaxed and move into a positive frame of mind, with the feeling that the learning is going to be easy and funny

2. Active concern

This involves the active presentation of the material to be learned. For example, in a foreign language course, there might be the dramatic reading of a piece of text, accompanied by classical music.

3. Passive Concern

The students are now invited to relax and listen to some Baroque music, with the text being read very quietly in the background. The music is specially selected to bring the students into the optimum mental state for the effortless acquisition of the material.

4. Practice

The use of a range of games, puzzles, etc, to review and consolidate the learning.

Suggestion is at the heart of Suggestopedia. Lozanov claims that his method is different from hypnosis and other forms of mind control because they lack a "desuggestive-suggestive sense" and "fail to create a constant set up to reserves through concentrative psycho-relaxation."

\section{The Techniques of Suggestopedia}

Anthony (in Brown, 2000) says that techniques are the specific activities manifested in the classroom that are consistent with a method and therefore in harmony with an approach as well. Technique is consisting of a wide variety of exercises, activities, or devises used in the language classroom for realizing lesson objectives. In Suggestopedia, there some techniques are used. Those are described below by Lozanov (2000).

1. Classroom set-up

This is emphasis in pleased on creating a physical environment that doesn't feel like a normal classroom and make the students 
feel like a relaxed a comfortable as possible.

2. Visualization

The students are asked to close their eyes and visualize scenes and events. It is to help them relax, facilitate positive suggestion and encourage creativity from the students.

3. New identity

In this case, the students select of target language name and/or occupation that places them "inside" the language they are learning

4. Role-play

Role play is one method of maximizing students' activities in the class and ensuring that the students get an optimum level of practice during their limited time. In these activities, the students use target language to perform a rule in role play. Role play also provides varieties of interactional activity and takes the focus of the class away from the teacher (p.84-86).

\section{Design of Suggestopedia}

Design in Suggestopedia consists of objective, syllabus, learning activities, roles of learners, teachers, and materials. The functions of each design are different. Those will be explained below:

1. Objectives

According to Richards \& Rodgers (2012), the objective of Suggestopedia is to deliver advances conversational proficiency quickly. It based its learning claim on student mastery of prodigious lists of vocabulary pair, and, indeed, suggests to the students that it is appropriate that they set such goals for themselves. The main objective of teaching is not memorization, but the aim is to understand and creates a creative solution of problems.

2. The syllabus

It is criteria for the selection and organization of linguistic and or subject- matter content. The syllabus is made to guide in teaching learning process.

3. Types of learning and teaching activities

Based on Stevick in Richards \& Rodgers (2012) the types of activities that are more original to Suggestopedia are the speaking activities, which concern the text and text vocabulary of each unit. In this activity, first, the students read and discuss a new narrative text with the teacher. Second, the students relax comfortably in reclining chairs and listen to the teacher that read the text in a certain way. Third, the material is acted out by the instructor in a dramatic manner over a background of the special musical form described preciously. During this phase students learn back in their chairs and breathe deeply and regularly as instructed by the teacher.

4. Learner roles

According to Richards \& Rodgers (2012), the roles that students have are:

a. Learners must not try to figure out, manipulate, or study the material presented 
but they must maintain a pseudo-passive state.

b. The students should build selfconfidence, spontaneity, and receptivity.

c. Group of learners is ideally socially homogeneous, twelve in number, and divided equally between men and women. Learners sit in a circle, which encourages faceto-face exchange and activity participation.

\section{Teaching Speaking Using Suggestopedia Method}

In teaching and learning speaking the use of method is very important, because it can make the teacher easy to give information or material to the students. The method which can be used is Suggestopedia. Suggestopedia is the method which uses music or videos in teaching learning process.

The use of Suggestopedia in teaching learning speaking is much needed; Suggestopedia can motivate more of students' mental potential to learn and which obtained by suggestion because with this method the teacher can give relax situations, so the students can get the material easily. With music the students can imagine their think and then they can describe their imagination to others. From the activities in Suggestopedia, the students can master more speaking.

\section{RESEARCH METHODOLOGY}

he research was conducted from
March $23^{\text {rd }}$ to April 2 2, 2018.
There were some steps in doing this research. First was giving pretest.
Second was giving the sample treatment. The last was giving posttest to group whether students got different result or not.

Considering the research subject, The population in this study was taken from the first semester of the class in STIT Muhammadiyah, Tanjung Redeb,Berau in the academic year 2018/2019 where it is located in Jendral Sudirman street, Berau, East Kalimantan. Population is the whole research subjects. For sampling, the writer used purposive sampling technique by taking one class as sample from one of the first semester class, namely is class A. This class had 32 (thirty two) numbers of student. Then to research this class the writer would teach the sample speaking ability by Suggestopedia method. Sample is a representative of the population which studied or to generalize research results to the population the technique of collecting samples used in this study subjects were not randomly assigned.

In obtaining the data, the writer used the test instrument in this research. The writer administered two tests, they are pretest and posttest. After the pretest on groups was held, the next step was analyzing the output data. Before performing in t-test, the output data of pretest should fulfill the criteria underlying t-test as stated that Nunan (2012), such as: 1) The data should have a normal distribution. 2) The variance of the sample of group must be homogenous.

\section{FINDING AND DISCUSSION} retest Score Analysis

The following table can tell mean of score and standard deviation of 
the pretest score from one group sample.

Table 1. Descriptive Statistics on Pretest Score

\begin{tabular}{llllll}
\hline & & & & \multicolumn{1}{c}{$\begin{array}{c}\text { Std. } \\
\text { N }\end{array}$} \\
& Minimum Maximum & Mean & Deviation \\
\hline Pretest & 32 & 11,00 & 17,00 & 13,8095 & 1,36452 \\
ValidN & 32 & & & & \\
(listwise) & & & & \\
\hline
\end{tabular}

From the score of pretest, it could be showed that the highest scoring of speaking test was 17 and the lowest score was 11 with mean 13, 8095. Nevertheless the computation above could not represent whether the means of the pretest were significantly different. Therefore paired-sample t-test was performed to compare the mean both of pretest and posttest

\section{Normality of Distribution}

In the test, the level of significance was set up 0.05. Based on table 4.2, it shows the Asymp. Sig. (2-tailed) pretest of data is 0.219 . The result suggests that the null hypothesis is not rejected however the alternative hypothesis is rejected. Therefore, ( $\mathrm{HO})$ is accepted that the pretest scores of group are normally distributed. The level of significance in the test was established at 0.05. Moreover in the table 4.3 the Asymp.sig was higher than the level of determined significance (0.05), which also can be stated that $0.916>0.05$. It indicates that the null hypothesis is not rejected but the alternative is rejected. It draws a conclusion that the variances data is homogenous. It also implies that the analysis of t-test can be conducted since the data were normally distributed and the variance was homogenous.

\section{Posttest Score Analysis}

The following table is the description of posttest score.

Table 2. Descriptive Statistics on Posttest Score

\begin{tabular}{llllc}
\hline \multicolumn{3}{c}{ N Minimum Maximum } & Mean & $\begin{array}{c}\text { Std. } \\
\text { Deviation }\end{array}$ \\
\hline Posttest 32 & 9 & 21 & 16,1613 & 2,47786 \\
$\begin{array}{c}\text { Valid N } 32 \\
\text { (listwise) }\end{array}$ & & & & \\
\hline
\end{tabular}

Based on the table above, it could be showed that the highest score on speaking test was 21 and the lowest score was 9 with mean 16,16. It was higher than the mean of pretest. Nevertheless it could not conclude yet that the means were significant.

\section{Result of T-Test Computation}

The computation of difference means between pretest and posttest was aimed to find out significant differences between pretest and posttest means.

The mean of pretest score of the class was 12.97 with standard deviation 2.041 and the mean of posttest score was 16.16 with standard deviation 2.478. The significant difference between means of posttest which is higher than pretest can be seen in the following chart.

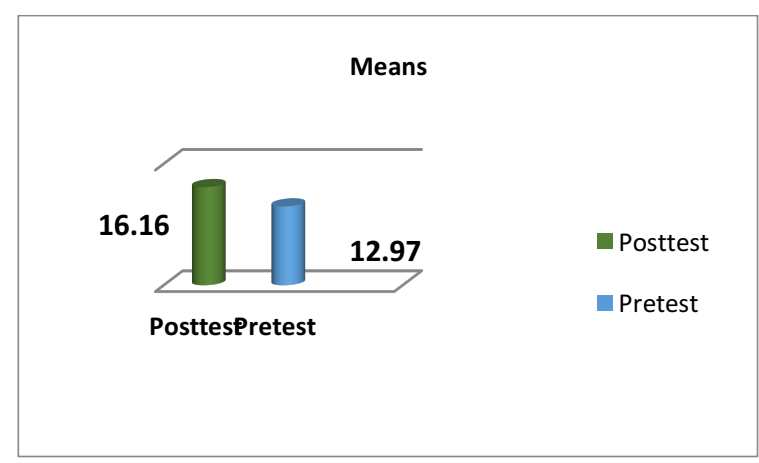

Figure 1. Difference Means between Posttest and Pretest 
The students' speaking skill on pretest scores mean improved 3.194 from 12,968 became 16.161 on posttest scores mean. It proves that treating students by using Suggestopedia method is effective to improve their speaking ability.

Table 3. Paired Sample Correlations

\begin{tabular}{llccc}
\hline & & N & Correlation & Sig. \\
\hline Pair & $\begin{array}{l}\text { Pretest \& } \\
\text { 1 }\end{array}$ & 32 & 0,574 &, 001 \\
\hline
\end{tabular}

While the table 4.10 (paired sample correlations) above shows the result of correlations between the pretest and post-test, that is 0,574 and Sig. or probability was 0,001 . Because Sig. is lower than the level of significance $(0,000<0.05)$. It means there is positive correlations between pre-test and posttest on sample of group.

\section{Data Interpretation}

The result of a paired sample $t$ test was presented to find out the significance mean differences between students' posttest and pretest. Based on the findings, it could be seen from average pretest scores is 12.97 and the posttest score is 16.16 . It increased 3.19 point, which is meant that the implementation of Suggestopedia method gave the influence and it was effective to increase students' speaking ability. Besides, it also can be seen that the probability was lower than the level of significance $(0.000<0.05)$. That calculation is indicated that there was significant difference of means between students' posttest and pretest. Moreover, the findings of paired sample t-test gained the $\mathrm{t}$ obtained is 8.387 which was higher than the $\mathrm{t}$ critical in lined with $d f=$
31 (1.6955). In other words, the null hypothesis was rejected while the alternative hypothesis which state that there is significant effect in students' speaking ability after teaching by using Suggestopedia is accepted.

\section{CONCLUSION}

ccording to the finding and
discussions of the research, the
conclusion of this study has proven that Suggestopedia method is effective to increase students' speaking ability. The statistical computation result shows that the value of t-test calculation which showed $t_{\text {obtained }}$ is 8.387 was higher than $t_{\text {critical }}$ was 1.6955 at level of significance 0.05 , with $d f=31$. For that reason, the null hypothesis was rejected, but the alternative hypothesis which stated that there is significance difference in students' speaking ability after teaching by using Suggestopedia method was accepted.

\section{REFERENCES}

Brown, H. D. (2000). Principles of language Learning and Teaching. New York: Longman.

Jackson, R. L. (2010). Encyclopedia of Identity. Thousand Oaks, CA: SAGE.

Lozanov, G. (2000). Suggestology and Outlines of Suggestopedy. New York: Gordon and Breach.

Nunan, D. (2012). Research Methods in Language Learning. Cambridge: Cambridge University Press.

Nurgiyantoro, B. (2011). Penilaian dalam Pengajaran Bahasa dan Sastra. Yogyakarta: BPFE-Yogyakarta.

Richards, J. C., \& Renandya, W. A (Eds.). (2002). Methodology in Language Teaching: an Anthology of Current Practice. Cambridge: Cambridge 
University Press.

Richards, J. C., \& Rodgers, T. S. (2012).

Approaches and Methods in

Language Teaching. New York:

Cambridge University Press. 